\title{
The first mastectomy: truth or legend?
}

\author{
Luiz Marinho $1,2 *$ (iD
}

Radical breast mastectomy is tied to the name William Halsted. $\mathrm{He}$ is regarded as the pioneer in performing radical surgery as the effective way to treat breast cancer in $19^{\text {th }}$ century. Some publications record that the first radical mastectomy occurred in 1882 at New York ${ }^{1}$. However, there is record that it was occurred at John Hopkins Medical School in Baltimore 2 . There is two register to the year of the first surgery from professor Halsted, $1882^{3}$ and $1889^{4}$.

In 1984, Halsted published the 50 cases that he operated with a recurrence rate of 6\%, while in Europe the recurrence rate were from $51 \%$ to $82 \%$, because they did not use the surgical technique described by Halsted.

\section{LISTER AND BREAST CANCER SURGERY}

Joseph Lister, surgeon and chief of surgery at the University of Glasgow-Scotland, was researching some substance that could prevent contamination of surgical wounds. Suddenly, in the summer of 1867, Lister was approached by his sister, Isabella Lister Pinn. She had a breast cancer and she had already sought a surgeon in London and another in Edinburgh, Scotland. None of them accepted to treat her.

Lister had no way to refusing the treatment to his sister. He travelled to Edinburgh to discuss the situation with professor Syme, one of the doctors who had examined Isabella before. Syme was Lister's father-in-law and chief of surgery at Edinburgh Hospital.

Doctor Lister shared with his father-in-law that he had good results after surgery using carbolic acid as an antiseptic, and many patients have left the hospital in Glasgow without problems with surgical scaring, since he started using the antiseptic solution to prevent infections. Lister believed the germ theory and he was employing antiseptic treatment since he had read the papers from Louis Pasteur. Syme accepted the arguments of this former assistant. If there was any hope to Isabella, it was the surgery plus carbolic acid as a prevention the suppuration of the wound.
Lister returned from Edinburgh and devoted himself to working in the anatomy room from Glasgow's University, to familiarize himself with the anatomy of woman's chest.

In June 16,1867 , the patient was operated. Lister decided to carry out the operation in his own home, and the dining table was adapted to be an operating table. Lister feared that Isabella could more chance to have an infection if he made the surgery in the hospital. Chloroform was used to anesthetize Isabella. The instruments to the surgery had been dipped in carbolic acid. The gauze and everything that it would be used was sanitized with carbolic acid. Lister and three other surgeons also claimed their hands with carbolic acid 5 .

Hector Cameron was one of Lister's assistant and wrote that Lister believed that if hands and skin were thoroughly washed in carbolic lotion and instruments and drapes soaked in it, then a safe elective surgery could be undertaken ${ }^{6}$.

Lister removed the breast tissue, muscles and lymph nodes. It was the same surgery published by Halsted in 1894 . Isabella stayed in the Lister's house until she got well. Isabella's wound healed without suppuration due to Lister's careful application of carbolic acid during and after her procedure. She lived three years after the treatment at Glasgow, but she died because she had a relapse in the liver.

Lister published in The Lancet one paper entitled: Lister covered her chest. He did not announced a new technique surgery for breast cancer. The goal was to prevent surgery infection using carbolic acid. This paper was published in 1875 , exactly 19 years before the paper published by Halsted ${ }^{7}$.

Isabella's story was one of the stories of the life of Lister in Scotland. Lister had no alternative, he must help Isabella. He continued to research how to prevent infections. Halsted opened the way for mastologists around the word. Halsted was for us as the lighthouse of knowledge that showed us what and how we could treat women with breast cancer. Just Neil Armstrong in the moon, Halsted gave the first step to a new era of treatment of breast cancer.

1 Universidade do Oeste de Santa Catarina - Joaçaba (SC), Brazil.

${ }^{2}$ Hospital Unimed - Chapecó (SC), Brazil.

*Corresponding author: lbmarinho@uol.com.br

Conflict of interests: nothing to declare.

Received on: 10/01/2020. Accepted on: 10/17/2020. 


\section{REFERENCES}

1. Kinne WD. Primary treatment of breast cancer. In: Harrys JH, Hellman S, Henderson CI, Kinne WD, eds. Breast disease. $2^{a}$ ed. Pennsylvania: Lippincott; 1991. Chapter 16, p. 347 .

2. Wagner Jr. BF. History of breast disease and its treatment. In: Wagner Jr. BF, ed. The breast. Philadelphia: Sauders, Bland \& Copeland; 1991. Chapter 1., p. 10.

3. Moura DL. História do tratamento cirúrgico do cancro da mama: empirismo e ciência. Rev Port Cir. 2013;(27):41-58.
4. Cavalcante PF. História Halsted antes da fama. Mastology News. 2016;20:13.

5. Fitzharris L. The Butchering Art. In: Lane A, ed. The Storm. Great Britain: Clays Ltd, St Yves plc; 2017. Chapter 9, p. 177.

6. Jones PF. The friendship of Joseph Lister and Hector Cameron. J Med Biogr. 2001;9(3):143-50. https://doi. org/10.1177/096777200100900304

7. Fitzharris L. The Butchering Art. In: Notes. Great Britain: Clays Ltd, St Yves plc; 2017, p. 259. 